\title{
An Estimate of Recoverable Heavy Oil Resources of the Orinoco Oil Belt, Venezuela
}

The U.S. Geological Survey estimated a mean volume of 513 billion barrels of technically recoverable heavy oil in the Orinoco Oil Belt Assessment Unit of the East Venezuela Basin Province; the range is 380 to 652 billion barrels. The Orinoco Oil Belt Assessment Unit thus contains one of the world's largest recoverable oil accumulations.

\section{Introduction}

The Orinoco Oil Belt Assessment Unit (AU) of the La Luna-Quercual Total Petroleum System encompasses approximately $50,000 \mathrm{~km}^{2}$ of the East Venezuela Basin Province that is underlain by more than 1 trillion barrels of heavy oil-in-place (fig. 1) (Fiorillo, 1987). As part of a program directed at estimating the technically recoverable oil and gas resources of priority petroleum basins worldwide, the U.S. Geological Survey (USGS) estimated the recoverable oil resources of the Orinoco Oil Belt AU. This estimate relied mainly on published geologic and engineering data for reservoirs (net oil-saturated sandstone thickness and extent), petrophysical properties (porosity, water saturation, and formation volume factors), recovery factors determined by pilot projects, and estimates of volumes of oil-in-place.

The East Venezuela Basin is a foreland basin south of a fold belt (fig. 2). The progressive west-to-east collision of the Caribbean plate with the passive margin of northern South America in the Paleogene and Neogene formed a thrust belt and foreland basin that together compose the East

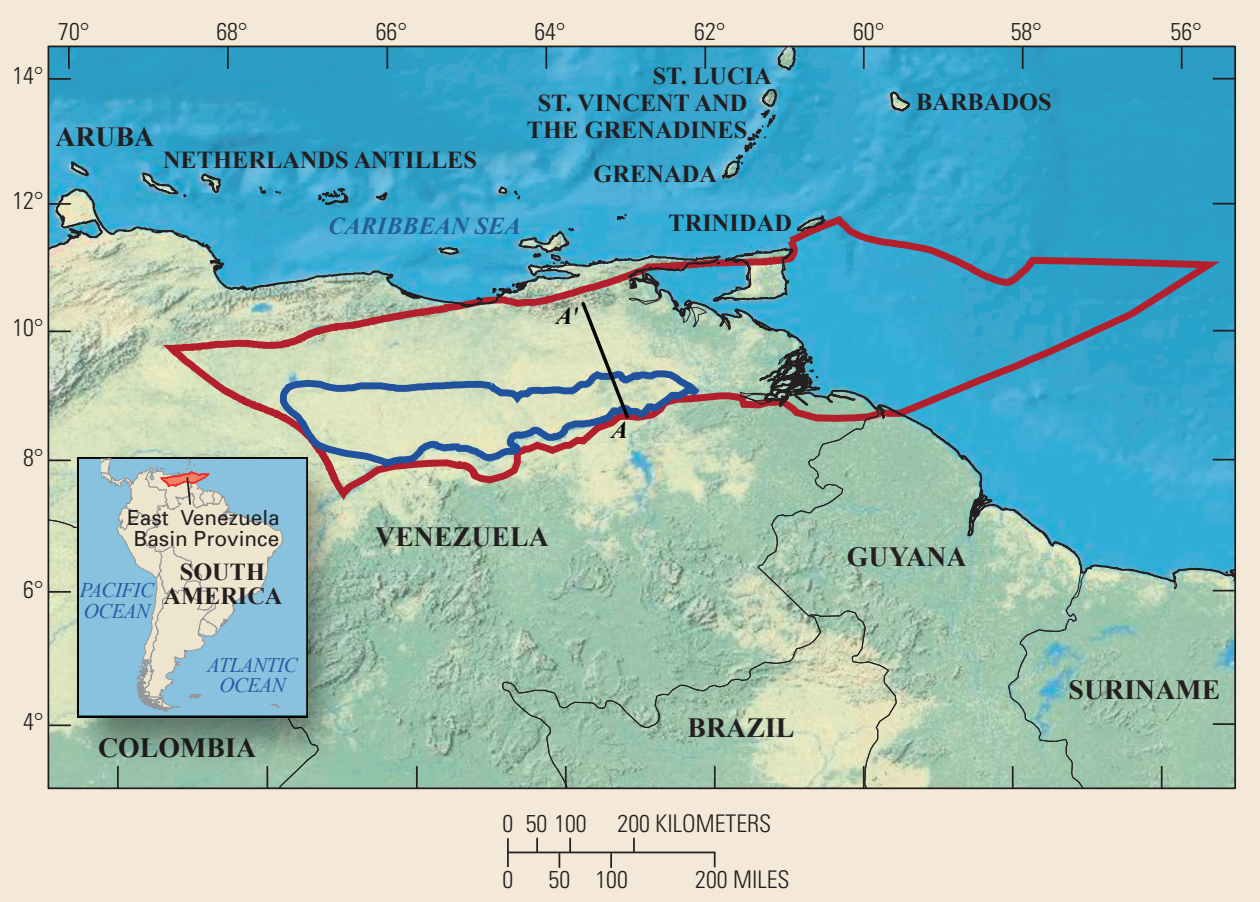

\section{EXPLANATION}

Orinoco Oil Belt Assessment Unit

East Venezuela Basin Province

Figure 1. Map showing the location of the Orinoco Oil Belt Assessment Unit (blue line); the La Luna-Quercual Total Petroleum System and East Venezuela Basin Province boundaries are coincident (red line).

Venezuela Basin Province. Thrust faults associated with the fold belt caused lithospheric loading and basin formation, and the resulting burial placed Cretaceous and possibly older petroleum source rocks into the thermal window for the generation of oil (Parnaud and others, 1995; Summa and others, 2003). The oil migrated updip from the deeper basin to the shallow southern basin platform, forming the Orinoco Oil Belt. The oil is considered to be concentrated along a forebulge that formed south of the foreland basin (Bartok, 2003).

The heavy oil in the Orinoco Oil Belt AU is largely contained within fluvial, nearshore marine, and tidal sandstone reservoirs of the Miocene Oficina Formation (Kopper and others, 2001; Bejarano, 2006).
The reservoir sandstones, although porous and permeable, are characterized by several depositional sequences with considerable internal fluid-flow heterogeneity caused by juxtaposition of different facies and by shale barriers that reduce recovery efficiency. Sandstone reservoirs range in depth from 150 to 1,400 meters, and they contain heavy oil with a range of gravities from 4 to 16 degrees API. Viscosities are generally low, ranging from 2,000 to 8,000 centipoises (Dusseault, 2001).

\section{Methodology and Input Data}

In addition to the standard USGS methodology for assessing continuous oil accumulations such as those in the 
Orinoco Oil Belt (Crovelli, 2000), we used reservoir data, petrophysical data, oil-in-place estimates, and recovery factors taken from studies of the Orinoco Oil Belt to develop five other approaches for estimating recoverable resources and to adequately represent the geologic and engineering uncertainty in the assessment. Key data used in the assessment are summarized in table 1 . The estimates of volumes of recoverable oil and associated gas reported here reflect the distribution of mean estimates obtained by the six methodologies applied to the Orinoco Oil Belt AU (table 2).

\section{Estimates of Original Oil-in-Place}

A comprehensive study by Petroleos de Venezuela S.A. (PDVSA) established the magnitude of the original oil-in-place
(OOIP) at 1,180 billion barrels of oil (BBO), a commonly cited estimate for the Orinoco Oil Belt (Fiorillo, 1987); PDVSA recently revised this value to more than 1,300 BBO (Gonzalez and others, 2006). In this study the median OOIP was estimated at $1,300 \mathrm{BBO}$ and the maximum at 1,400 BBO. The minimum OOIP was estimated at $900 \mathrm{BBO}$, given the uncertainty of regional sandstone distribution and oil saturation (Fiorillo, 1987).

\section{Estimates of Recovery Factor}

Recovery factor, or that percentage of the OOIP that is determined to be technically recoverable, was estimated from what is currently known of the technology for recovery of heavy oil in the Orinoco Oil Belt
AU and in other areas, particularly California, west Texas, and western Canada. The minimum recovery factor was estimated to be 15 percent, the recovery expected for cold production using horizontal wells. The median recovery factor was estimated to be 45 percent, on the assumption that horizontal drilling and thermal recovery methods might be widely used. The maximum recovery factor was estimated to be 70 percent, on the assumption that other recovery processes, in addition to horizontal drilling and steam-assisted gravity drainage, might eventually be applied on a large scale in the Orinoco Oil Belt AU (Dusseault, 2001; Curtis and others, 2002; Acasio and Regardiz, 2006; Fernandez and Bashbush, 2008).

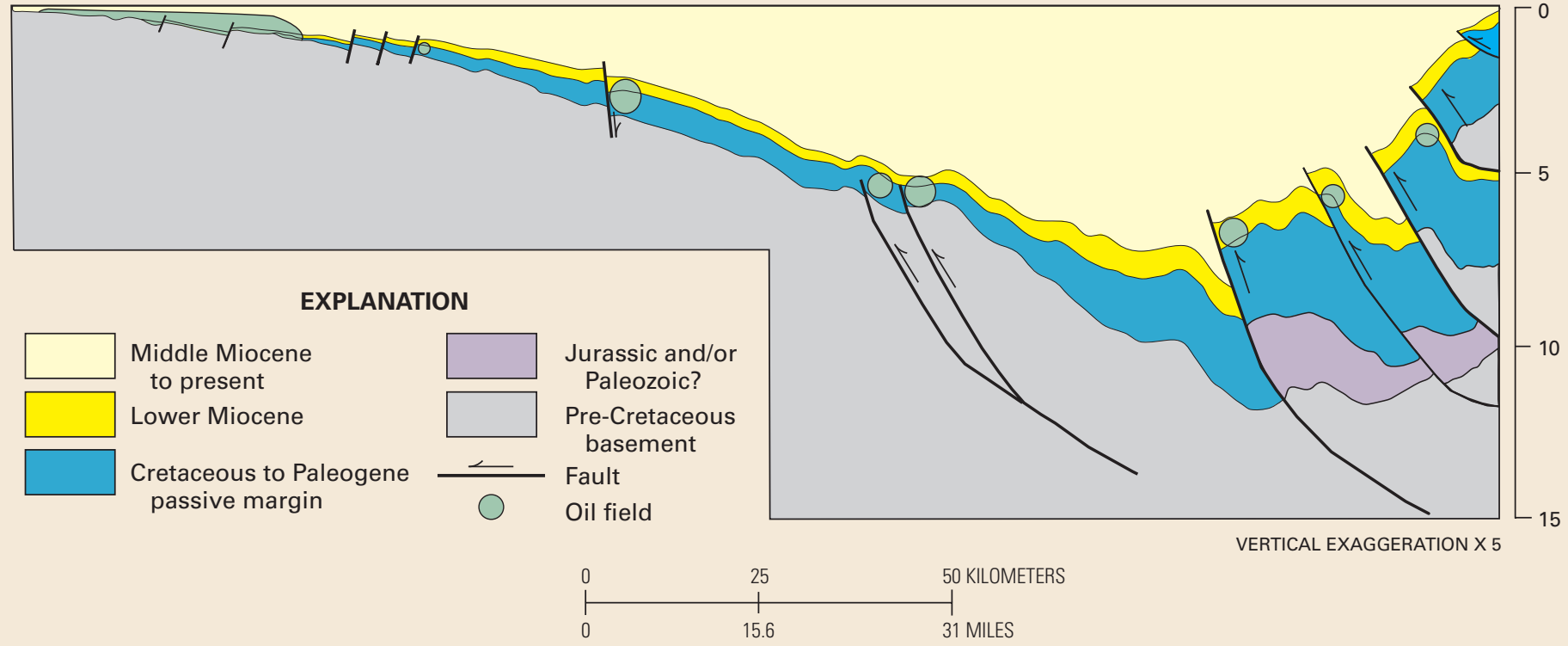

Figure 2. Schematic structural cross section of the East Venezuela Basin showing the updip position of the Orinoco Oil Belt relative to the deeper part of the East Venezuela Basin. Oil generated from thermally mature Cretaceous and possibly older source rocks in the deeper part of the basin migrated updip to form the accumulation in the Orinoco Oil Belt (after Jacome and others, 2003). 
Table 1. Key input data for assessment of Orinoco Oil Belt Assessment Unit.

[\%, percent; BBO, billion barrels of oil; $\mathrm{ft}$, feet; scf/bbl, standard cubic foot per barrel]

\begin{tabular}{|c|c|c|c|}
\hline & Minimum & Median & Maximum \\
\hline Orinoco oil-in-place (BBO) & 900 & 1,300 & 1,400 \\
\hline Recovery factor (\%) & 15 & 45 & 70 \\
\hline Net oil-saturated sandstone thickness (ft) & 1 & 150 & 350 \\
\hline Porosity (\%) & 20 & 25 & 38 \\
\hline Water saturation $(\%)$ & 10 & 20 & 25 \\
\hline Formation volume factor & 1.05 & 1.06 & 1.08 \\
\hline Gas/oil ratio (scf/bbl) & 80 & 110 & 600 \\
\hline
\end{tabular}

Table 2. Orinoco Oil Belt Assessment Unit assessment results.

[BBO, billion barrels of oil; TCFG, trillion cubic feet of gas; NGL, natural gas liquids; BBNGL, billion barrels natural gas liquids. Results shown are fully risked estimates. F95 represents a 95 percent chance of at least the amount tabulated. Other fractiles are defined similarly]

\begin{tabular}{|c|c|c|c|c|c|c|c|c|c|c|c|c|c|}
\hline \multirow{3}{*}{$\begin{array}{l}\text { Total Petroleum System } \\
\text { (TPS) } \\
\text { and Assessment Unit } \\
\text { (AU) }\end{array}$} & \multirow{3}{*}{$\begin{array}{l}\text { Field } \\
\text { Type }\end{array}$} & \multicolumn{12}{|c|}{ Total Undiscovered Resources } \\
\hline & & \multicolumn{4}{|c|}{ Oil (BBO) } & \multicolumn{4}{|c|}{ Gas (TCFG) } & \multicolumn{4}{|c|}{ NGL (BBNGL) } \\
\hline & & F95 & $\mathbf{F} 50$ & F5 & Mean & F95 & F50 & F5 & Mean & F95 & F50 & F5 & Mean \\
\hline \multicolumn{14}{|l|}{ La Luna-Querecual TPS } \\
\hline Orinoco Oil Belt AU & Oil & 380 & 512 & 652 & 513 & 53 & 122 & 262 & 135 & 0 & 0 & 0 & 0 \\
\hline
\end{tabular}

\section{Probability Distributions of Petrophysical and Reservoir Properties}

Oil-saturated sandstones in the Orinoco Oil Belt AU are largely unconsolidated (Dusseault, 2001). The values used in the assessment for porosity, water saturation, net oil-saturated sandstone thickness, and formation volume factor are shown in table 1. Net thickness and extent of oil-saturated sandstone were obtained from a published map that resulted from a comprehensive PDVSA study of the Orinoco Oil Belt (Fiorillo, 1987).

\section{Summary of Results}

The assessment of technically recoverable heavy oil and associated gas resources is shown in table 2 . The mean of the distribution of heavy oil resources is about $513 \mathrm{BBO}$, with a range from 380 to about $652 \mathrm{BBO}$. The mean estimate of associated dissolved-gas resource is 135 trillion cubic feet of gas (TCFG), with a range from 53 to 262 TCFG. No attempt was made in this study to estimate either economically recoverable resources or reserves within the Orinoco Oil Belt AU. Most important, these results do not imply anything about rates of heavy oil production or about the likelihood of heavy oil recovery. Also, no time frame is implied other than the use of reasonably foreseeable recovery technology.

\section{References Cited}

Acasio, Y., and Regardiz, K., 2006, Opportunity for a SAGD pilot test implementation in a zone in initial phase of operation, Ayacucho area, Orinoco Belt: World Heavy Oil Conference, Beijing, China, November 12-15, 2006, Proceedings, Paper 2006-771, 13 p.

Bartok, Peter, 2003, The peripheral bulge of the Interior Range of the Eastern Venezuela basin and its impact on oil accumulations, in Bartolini, C., Buffler, R.T., and Blickwede, J., eds., The Circum-Gulf of Mexico and the Caribbean-Hydrocarbon habitats, basin formation, and plate tectonics: American Association of Petroleum Geologists Memoir 79, Chap. 41, p. 925-936.
Bejarano, C., 2006, Tertiary stratigraphy and sedimentary environments of the oil bearing sands of the Orinoco Oil Belt, Venezuela, South America: World Heavy Oil Conference, Beijing, China, November 12-15, 2006, Proceedings, Paper 2006-770, 7 p.

Crovelli, R.A., 2000, Analytic resource assessment method for continuous (unconventional) oil and gas accumulations - The "ACCESS" method: U.S. Geological Survey Open-File Report 00-044, 34 p.

Curtis, Carl, Kopper, Robert, Decoster, Eric, Guzman-Garcia, Angel, Huggins, Cynthia, Knauer, Larry, Minner, Mike, Kupsch, Nathan, Linares, Luz M., Rough, Howard, and Waite, Mike, 2002, Heavy-oil reservoirs: Oilfield Review, Autumn 2002, Schlumberger Oilfield Services Company, p. 30-51.

Dusseault, M.B., 2001, Comparing Venezuelan and Canadian heavy oil and tar sands, in Canadian International Petroleum Conference, Calgary, Alberta, Canada, June 12-14, 2001, Canadian Institute of Mining, Metallurgy, and Petroleum, Proceedings, Paper 2001-061, 20 p. 
Fernandez R., E.A., and Bashbush, J.L., 2008, Horizontal alternating steam drive process for the Orinoco Heavy Oil Belt in eastern Venezuela: Society of Petroleum Engineers/Petroleum Society/Canadian Heavy Oil Association, Paper SPE/PS/CHOA 117689, 13 p.

Fiorillo, G., 1987, Exploration and evaluation of the Orinoco Oil Belt, in Meyer, R.F., ed., Exploration for heavy crude oil and natural bitumen: American Association of Petroleum Geologists Studies in Geology 25, p. 103-121.

Gonzalez, O., Ernandez, J., Chaban, F., and Bauza, L., 2006, Screening of suitable exploitation technologies on the Orinoco Oil Belt applying geostatistical methods: World Heavy Oil Conference, Beijing, China, November 12-15, 2006, Proceedings, Paper 2006-774, 12 p.
Jacome, M.I., Kusznir, Nick, Audemard, Felipe, and Flint, Steve, 2003, Tectonostratigraphic evolution of the Maturin foreland basin-Eastern Venezuela, in Bartolini, C., Buffler, R.T., and Blickwede, J., eds., The Circum-Gulf of Mexico and the CaribbeanHydrocarbon habitats, basin formation, and plate tectonics: American Association of Petroleum Geologists Memoir 79, Chap. 33, p. 735-749.

Kopper, Robert, Kupecz, Julie, Curtis, Carl, Cole, Tony, Dorn-Lopez, Donald, Copley, Jeffery, Munoz, Alberto, Caicedo, Vladimir, and Suter, John, 2001, Reservoir characterization of the Orinoco Heavy Oil Belt; Miocene Oficina Formation, Zuata Field, Eastern Venezuelan Basin: Society of Petroleum Engineers, Paper SPE 69697, 16 p.
Parnaud, Francois, Gou, Yves, Pascual, J.C., Truskowski, Irene, Gallango, Oswaldo, Passalacqua, Herminio, and Roure, F., 1995, Petroleum geology of the central part of the East Venezuelan Basin, in Tankard, A.J., Suarez, R., and Welsink, H.J., eds., Petroleum basins of South America: American Association of Petroleum Geologists Memoir 62, p. 741-755.

Summa, L.L., Goodman, E.D., Richardson, M., Norton, I.O., and Green, A.R., 2003, Hydrocarbon systems of northeastern VenezuelaPlate through molecular scale-analysis of the genesis and evolution of the Eastern Venezuela Basin: Marine and Petroleum Geology, v. 20, p. 323-349.

\section{U.S. Geological Survey Orinoco Oil Belt Assessment Team:}

Christopher J. Schenk, Troy A. Cook, Ronald R. Charpentier, Richard M. Pollastro, Timothy R. Klett, Marilyn E. Tennyson, Mark A. Kirschbaum, Michael E. Brownfield, and Janet K. Pitman.

\section{For Further Information}

A publication detailing the methodologies used in the Orinoco Oil Belt AU assessment is in progress. Assessment results are available at the USGS Energy Program website, http://energy.cr.usgs.gov/oilgas/. 